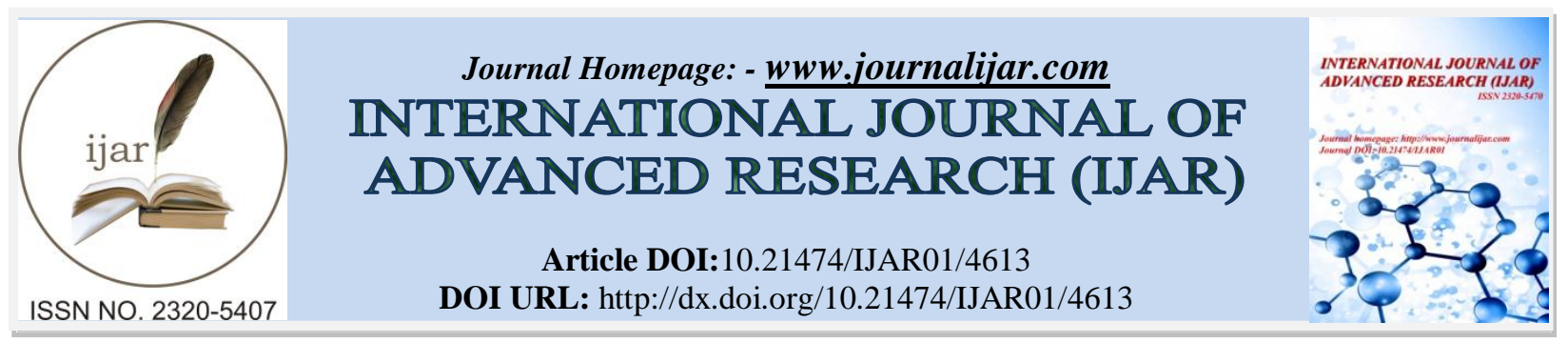

RESEARCH ARTICLE

\title{
NUTRITIONAL AND MICROBIAL STATUS OF EDIBLE MARINE FISH SCOMBEROMORUS GUTTATUS COLLECTED FROM LANDING CENTRE (PAMBAN) AND LOCAL MARKET IN RAMESWARAM, TAMILNADU, INDIA.
}

Merline $\mathbf{x}$ and * Chitrag.

Assistant Professor, Department of Zoology, Nirmala College for Women, Coimbatore, Tamilnadu.

\section{Manuscript Info}

........................

Manuscript History

Received: 25 April 2017

Final Accepted: 27 May 2017

Published: June 2017

Key words:-

Scomberomorus guttatus, proximate composition, landing centre, TVC.

\section{Abstract}

Fish as a source of "rich food for poor people" can play an important role in improving food security and nutritional status. Evaluating the proximate composition of food fish is the most important aspect in fish nutrition. The present study deals with the nutritional and microbial qualities of commonly available edible marine fish Scomberomorus guttatus collected from landing centre (Pamban) and local market in Rameswaram, TamilNadu. From the results the physicochemical parameters ( $\mathrm{pH}$ and moisture) of market samples of Scomberomorus guttatus are found to be higher than the sample collected from landing centre. Protein, carbohydrate, lipid and ash contents were analyzed and the results showed that landing centre samples had higher protein $(18.2 \mathrm{~g} / 100 \mathrm{~g})$ and carbohydrate contents $(6.0 \mathrm{~g} / 100 \mathrm{~g})$ than the market samples, whereas lipid $(0.13 \mathrm{~g} / 100 \mathrm{~g})$ and ash $(1.78 \mathrm{~g} / 100)$ contents were higher in market sample. Landing centre sample showed that the lowest total bacterial count of $0.38 \times 10^{5}$ $\mathrm{cfu} / \mathrm{g}$, than the market sample $\left(0.45 \times 10^{5} \mathrm{cfu} / \mathrm{g}\right)$.

Copy Right, IJAR, 2017,. All rights reserved.

\section{Introduction:-}

The fisheries sector makes an essential contribution to human development and food and nutrition security throughout the world, supplying vital nutrition to millions of people. Fish are an excellent source of high-quality protein, vitamins and minerals rich food for young as well as old age people. Fish and fish products are very important source of income and high market value. There are various reasons for the merits of eating fish. One such reason is that fish is less tough and more digestible when compared with beef, mutton, chicken and bush meat. It is a good source of sulphur and essential amino acid such as lysin, leucine, valine and arginine (Oladipo and Bankole, 2013). Fish is currently being used as a good tool for food therapy and source of therapeutic substances for the treatment of coronary diseases, auto immune disease, malnutrition and anaemia.

Biochemical composition of flesh is a good indicator for the fish quality (Hernandez et al., 2001), physiological condition and habitat of fish. Various species of fish do not provide the same nutrient profile to their consumer and the nutritive value of fish varies with season (Varlijenet al., 2003).

Freezing does not prevent spoilage of fish because of autolytic activities and chemical changes occurring in fish after harvest. The degeneration of fish is accelerated by microorganism associated with aquatic environment as well as contaminated during post -harvest handling. When fish dies microorganisms on the surface as well as gut and 
gills begins to utilize the fish protein and food nutrient resulting in loss of nutritional value. Microbial activities create undesirable changes like off-flavors, texture and appearance.

However, fish are susceptible to a wide variety of bacterial pathogens, most of which are capable of causing disease and are considered by some to be saprophytic in nature. Bacterial contamination in food often results in food spoilage as well as life threatening health hazards like food poisoning. Prevention thus helps in the preservation of food quality and public health enhancement.

Sidiket al., (2010) reviewed that the sensitivity of fish landings to some meteorological parameters. Popovicet al., (2010) analyzed the microbiological quality of marketed fresh and frozen seafood caught off the Adriatic Coast of Croatia. Sutharshiny and Sivashanthini (2011) examined the proximate composition of Scomberoidslysan, Scomberoidestol and Scomberiodescommersonianus fish species in Srilanka.Joshi and Bhoir (2011) studied the histamine forming bacteria in commercial fish samples of Kalyan city.The present study deals with the estimation of nutritional and microbial count of edible marine fish, Scomberomorusguttatus in local market and landing centre in Rameswaram, south east coast of Tamilnadu, India.

Table 1:- Proximate composition and microbial status of Scomberomorusguttatus collected from landing centre (Pamban) and local fish market in Rameswaram, TamilNadu

\begin{tabular}{|c|c|c|c|}
\hline S.NO & Parameters & & Market \\
\hline & & Landing centre & 6.68 \\
\hline 1 & $\mathrm{pH}$ & 6.6 & 76.6 \\
\hline 2 & Moisture $(\mathrm{g} / 100 \mathrm{~g})$ & 73.6 & 17.8 \\
\hline 3 & Protein $(\mathrm{g} / 100 \mathrm{~g})$ & 18.2 & 3.6 \\
\hline 4 & Carbohydrate $(\mathrm{g} / 100 \mathrm{~g})$ & 6 & 0.13 \\
\hline 5 & Lipid $(\mathrm{g} / 100 \mathrm{~g})$ & 0.06 & 1.78 \\
\hline 6 & Ash $(\mathrm{g} / 100 \mathrm{~g})$ & 1.63 & 0.45 \\
\hline 7 & Total viable count $(\mathrm{cfu} / \mathrm{g})$ & 0.38 & \\
\hline
\end{tabular}

\section{Values are represented as mean}

Table 2:-Isolation of amine forming bacterias and fungal species of Scomberomorusguttatus collected from landing centre (Pamban) and local fish market in Rameswaram, TamilNadu

\begin{tabular}{|l|c|c|c|}
\hline S.NO & Organisms & Landing centre (Pamban) & $\begin{array}{c}\text { Local market } \\
\text { (Rameswaram) }\end{array}$ \\
\hline 1 & E.coli & + & + \\
\hline 2 & Klebsiella pneumonia & - & + \\
\hline 3 & Staphylococcus aureus & - & - \\
\hline 4 & Proteus vulgaris & - & - \\
\hline 5 & Pseudomonas aeruginosa & - & - \\
\hline 6 & Salmonella typhimurium & - & - \\
\hline 7 & Aspergillusniger & - & - \\
\hline 8 & Microsporumcanis & - & \\
\hline 9 & Fusariumoxysporum & - & \\
\hline
\end{tabular}

\section{Materials and Methods:-}

\section{Sample collection and Preparation:-}

The fresh raw Scomberomorusguttatus were collected from landing centre at Pamban and from local fish market in Rameswaram, Ramnadu district, TamilNadu, India.

The collected samples were immediately placed in ice box containing crushed ice, kept cold and transported to the laboratory. The samples were beheaded, gutted, washed and filleted. Then the known weights of muscle samples were homogenate and filtered and then used for further analysis. 


\section{Physico- chemical Analysis:- Measurement of pH:-}

The sardine samples $(10 \mathrm{~g})$ were homogenized in sterile blenders with $10 \mathrm{ml}$ of distilled water to make thick slurry. The $\mathrm{pH}$ of this slurry was then measured using a pH meter (Eco tester $\mathrm{pH} 1$ ), where three readings were recorded and the average was calculated (Ronald and Ronald, 1991).

\section{Estimation of moisture: (Jain and Singh, 2000):-}

A known quantity of the sample is taken in a weighed fish and the moisture is removed by heating in a hot air oven. Finally it is cooled in desiccators and weighed. The difference between the weight of the sample before and after drying gives the moisture content and it is usually expressed as percentage (1\%) of the weight of the sample.

\section{Biochemical Analysis:-}

The total protein and carbohydrate content of the muscle tissues of fish was estimated by following the method of Lowry et al. (1951) and Hedge and Hofreiter (1962). Total lipid content was determined by Folchet al. (1957) and ash content was estimated using hot air oven method.

\section{Total viable count and isolation of microorganisms:-}

One gram $(1 \mathrm{~g})$ of fish sample was dissolved in sterile deionized water and serially diluted. One milliliter (1ml) of appropriate dilutions was seeded on plate count agar using spread plate method, and the medium was then incubated at $37^{\circ} \mathrm{C}$ for 24 hours. The plate count agar was examined and colonies present were counted and recorded after incubation at $37^{0} \mathrm{C}$ for 24 hours to get the total colony count in cfu/g. Amine forming bacteria and fungus species were isolated using different agar medium.

\section{Results and Discussion:-}

In India, among the marine water fish species, Scomberomorusguttatusare very delicious, nutritious and popular to consumers. The present study deals with nutritional and microbial status of commercially important Scomberomorusguttatus and the results were tabulated (Table-1).

$\mathrm{pH}$ and lipid values of fish meat are very important for shelf life and consumer choice. $\mathrm{pH}$ can act as indicators of the fish freshness as it start with low reading at the early stage of storage which means the nutritional state was still good and then increased when the fish had been stored for certain period of storage can determine the state of it freshness. Meat quality traits including fat and $\mathrm{pH}$ will be important in determining meat price and profits in the near future. In this present investigation, the $\mathrm{pH}$ value and the lipid content of Scomberomorusguttatus collected from the landing centre is 6.6 and $0.06 \mathrm{~g} / 100 \mathrm{~g}$ and the local market is 6.68 and $0.13 \mathrm{~g} / 100 \mathrm{~g}$ respectively. The range of lipid content in edible part is approximately $0.5-18 \%$. This depends on seasonal variation in feeding habits and regional difference in basic foods and nutrients (Bulliyaet al., 1997).

The moisture content of the samples from landing centre and market were found to be $73.6 \%$ and $76.6 \%$ respectively. The percentage of moisture in Scomberomorusguttatus muscle tissues was in acceptable level (70$80 \%$ ), which may be due to the stable levels in the environmental locations where the fish was collected.

Proteins are the most versatile macromolecules in living system and several crucial functions in all biological process. Fish received increased attention as potential source of animal protein and essential nutrients for human diets. Fish is a good low calorie, high protein choice to assist in weight lose for human beings. The examined fish Scomberomorusguttatusbelongs to high protein ranges from $17.8-18.2 \mathrm{~g} / 100 \mathrm{~g}$ and low lipid ranges from $0.06-$ $0.13 \mathrm{~g} / 100 \mathrm{~g}$. From the results, the protein content of Scomberomorusguttatus collected from the landing centre is $18.2 \mathrm{~g} / 100 \mathrm{~g}$ and the local market is $17.8 \mathrm{~g} / 100 \mathrm{~g}$. This conforms to the report of Sutharshiny and Sivashanthini (2011) the fish of scomberoides species examined belongs to high protein $(21.68 \pm 0.65 \%)$, low lipid $(0.89 \pm 0.005 \%)$ category.

The carbohydrate content was relatively low when compared to protein content of the samples. The recorded carbohydrate content of Scomberomorusguttatus collected from the landing centre and market were 6.0. $\mathrm{g} / 100 \mathrm{~g}$ and $3.6 \mathrm{~g} / 100 \mathrm{~g}$ respectively. Generally fish have very low levels of carbohydrate. The average carbohydrate contents in the fishes ranged between 1.21 and $3.2 \mathrm{~g} / 100 \mathrm{~g}$. The low value of carbohydrates recorded in the present study suggest that glycogen in many marine animals does not contribute significantly to the total reserves in the body (Jayasreeet 
al., 1994).Very few species were Scomberomorusguttatusand Sardinellalongiceps with about $3.6 \%$ and $6.0 \%$ respectively.

Ash is a measure of the mineral content of any food including fish. The observed ash concentration in Scomberomorusguttatus collected from landing centre and market are 1.63 and $1.78 \mathrm{~g} / 100 \mathrm{~g}$. This result gave identification that the fish samples are good sources of minerals such as calcium, potassium, zinc, iron and magnesium. The results obtained from the present study showed marine edible fish coincides with the value of ash content of commercial fishes and it is an agreement with the findings of Emmunuelet al., (2011), who reported that marine species contain rich sources of minerals. The concentrations of minerals and trace elements that contribute for the total ash contents are known to vary in fish depending their feeding behaviour, environment, ecosystem and migration even within the same area (Abdallahet al., 2007). It is the organic residue that remains after the organic matters burnt off.

The total viable count expressed as colony forming unit in one gram of sample (cfu/g). The total viable count of Scomberomorusguttatus collected from landing centre and market were $0.38 \times 10^{5} \mathrm{cfu} / \mathrm{g}$ and $0.45 \times 10^{5}$ respectively, which is below the permissible limit of International Commission on Microbiological Specification for foods (ICMSF) and French norms (FN) limits. In fact, ICMSF and FN have a limit of $4.70 \mathrm{log} \mathrm{cfu} / \mathrm{g}$.

The distribution of the bacterial and fungal species present in the sample (landing and market) is shown in table 2. A total of six bacterial and three fungal organisms were isolated from the landing and market sample. The isolated bacterial organisms were E.coli, Klebsiella pneumonia, Staphylococcus aureus, Proteus vulgaris, Pseudomonas aeruginosa and Salmonella typhimurium, fungal species were Aspergillusniger, MicrosporumcanisFusariumoxysporum. From the obtained results E.coliwere present in both the landing and market sample. E.coli may be isolated in environments polluted by fecal material and the organisms can multiply and survive for a long time in this environment. This conforms to the report of Sahuet al., (2013). Klebsiella pneumonia and Staphylococcus aureuswere found in market sample and Klebsiellahave been isolated from fish incriminated in scombroid poisoning. Staphylococcus species was the most frequent reported histamine-former in fish and fish products, accounting for nearly 50\% of histamine- forming microorganism. It can grow well at temperature of 30$37^{\circ} \mathrm{C}$. Fungal species were not detected in landing (Pamban) and local market (Rameswaram) samples.

\section{Conclusion:-}

From the results, it could be concluded that the examined fish sample Scomberomorusguttatus had the good nutritional composition. The high protein content confirmed that the selected species were good animal protein sources. The microbial quality of the selected fish from Pamban landing center and Rameswaram local market showed very low total viable count and the levels are acceptable. When compared to FAO and WHO (2012), this study clearly indicates that the microbial and proximate value obtained would be useful to help the consumers in choosing fish based on their nutritional value besides providing an update to food composition value.

\section{References:-}

1. Abdallahaand Mohamed, M.A. (2007) Speciation of trace metals in coastal sediments of EI-Max Bay South Mediterranean sea West of Alexandria, (Egypt). Environmental Monitoring Assessment ,132: 111-123.

2. Bulliya, G., Reddy P.C. and Reddanna, P.(1997) Traditional fish intake and fatty acid composition in fish consuming and non fish consuming populations, Asia Pacific Journal Clinical nutrition,6: 230-234.

3. Emmanuel, B.E., Oshinebo, C. and Aladetohun , N.F.(2011) Comparative analysis of the proximate compositions of Tarpon atlaticus and Clariasgariepinus from culture systems in South-Western Nigeria. African Journal of Food and Agriculture, Nutrition Development, 6: 11-16.

4. Folch, J.M., Lees, A. and Stanley, G.W, (1957) A simple method for isolation and purification of total lipids from animal tissues. Journal of Biological Chemistry, 226:497-508.

5. Hedge, J.E. and Hofreiter, B.T. (1962) Determination of reducing sugars, methods in carbohydrate chemistry. M.L Academy press, Newyork, 1: 388-389.

6. Hernandex, M.D.,Martinz F.J. and Garcia, B. (2001) Sensory evaluation of farmed sharpsnoutseabream (Diploduspuntazzo). Aquaculture International, 9:519-529.

7. Jain, P.C. and Singh,P.(2000) Moisture determination of jaggery in microwave oven. Sugar Technology, 2: 5152. 
8. Jayasree, V., Parulekar, A.H., Wahidulla, S. and Kamat, S.Y. (1994) Seasonal changes in biochemical composition of Holothurialeucospilota (Echinodermata). Indian Journal of Marine Science, 23:17-19.

9. Joshi, PA, Bhoir, VS. (2011) Study of histamine forming bacteria in commercial fish samples of kalayancity.Indian Journal of Current Science Research, 1(2):39-42.

10. Lowry,O.H., Rosebrough, N.J., Farr, A.L. and Dandall, R.J.(1951) Protein measurement with the folin phenol reagent. Journal Biological Chemistry, 193: 265-275.

11. Oladipo, I.C. and Bankole, S.O.(2013). Nutritional and microbial quality of fresh and dried Clariasgariepinus and Oreochromisniloticus. International Journal of Applied Microbiology and Biotechnology Research, 1: 1-6.

12. Popovic, T.N., Benussi, A., Dzidara, P., Coz- Rakovac, R., Strunjak- Perovic, L., Kozacinski, L., Jadan, .M. and Barlek- Gorski, D. (2010) Microbiological quality of marketed fresh and frozen seafood caught off the Adriatic coast of Croatia. VeterinarniMedicina, 55(5): 233-241.

13. Ronald, S.K. and Ronald, S. (1991). Pearson's composition and analysis of foods. Ninth edition, Longman Scientific and Technical. American Journal of Food and Nutrition, 3(2): 56-63.

14. Shau. S., Jana, A.K., Nath, S., Dora, K.C and Chowdhury, S. (2012) Management strategies for minimizing the incidence of pathogenic bacteria in seafood's at Kolkata fish market. International Journal of Innovative Research in Science, Engineering and Technology, 6 (1): 125-127.

15. Sidik, J.M., Aung, T. and Sing, A. (2010) Sensitivity of fish landings to some meterological parameters: A case study. American Journal of Environmental Science, 6(2):177-183.

16. Sutharshiny, S. and Sivashanthini, K. (2011) Proximate composition of three species of scomberoides fish from Srilankan waters. Asian Journal of Clinical Nutrition, 3(3): 103-111.

17. Varlijen,J., Sulic, S., Brmali J., Obersnel, L. and Kapovic, M. (2003) Lipid classes and fatty acid composition of Diplodus vulgaris and Conger conger originating from the Adriatic Sea. Food Technology and Biotechnology, 41: 149-156. 